\title{
Stimulation of rat placental lactogen-II (rPL-II) secretion by cultured trophoblasts by insulin: development of a rat placental cell culture system and effects of peptide hormones on rPL-II secretion in vitro
}

\author{
K. Kishi, M. Itoh, S. Kanamori, M. Hirashiba and M. Kawai \\ Kanzakigawa Laboratory, Shionogi Research Laboratories, Shionogi and Co. Ltd, Futaba-cho 3-1-1, \\ Toyonaka, Osaka 561, Japan
}

\begin{abstract}
The purpose of this study was to develop a primary culture system using serum-free medium for rat placental trophoblast cells and to investigate the factors that control rat placental lactogen-II (rPL-II) secretion in vitro. The placentae of day 13 pregnant rats were dissociated in Medium 199 containing $0.1 \%$ collagenase and $0.002 \%$ DNAase. Dissociated cells were fractionated into five segments by centrifugation through a $40 \%$ Percoll density gradient and incubated on rat tail collagen bed in medium SFM-101 for up to 7 days. Fraction B at the Percoll gradient density of $1.05 \mathrm{~g} \mathrm{ml}^{-1}$ was enriched with rPL-II-producing cells and the time course of rPL-II secretion was characterized by a rapid increase in the first 2 days, remaining at high values (mean: $14-16 \mathrm{ng} \mathrm{g}^{-1} \mathrm{DNA}$ ) for the following 2-3 days and decreasing thereafter. The rPL-II-producing cells from faction $B$ identified by immunocytochemical examination accounted for approximately $69 \%$ of total cultured cells and consisted of a few giant cells and polygonal cells. Growth factors (bovine insulin, $0.1-20 \mu \mathrm{g} \mathrm{ml}^{-1}$; recombinant human insulin-like growth factor (IGF)-I, IGF-II, $0.1-1.0 \mu \mathrm{g} \mathrm{ml}^{-1}$; murine epidermal growth factor (EGF), 0.001-10 $\mathrm{g} \mathrm{ml}^{-1}$ ), rat pituitary hormones (rat growth hormone, rat prolactin, $0.1-10 \mu \mathrm{g} \mathrm{ml}^{-1}$ ) and hypothalamic hormones (human growth hormone-releasing hormone $(\mathrm{GHRH})$, corticotrophin-releasing hormone (CRH), LHRH, $0.1-10 \mu \mathrm{g} \mathrm{ml}^{-1}$ ) were individually added to the culture medium to investigate the putative factors that directly control rPL-II secretion by the trophoblast cells. Insulin and GHRH stimulated rPL-II secretion in a dose-dependent manner and their effective doses were found to be $0.1 \mu \mathrm{g}$ insulin $\mathrm{ml}^{-1}$ and $1 \mu \mathrm{g}$ GHRH $\mathrm{ml}^{-1}$. IGFs, EGF, rat growth hormone, rat prolactin, CRH and LHRH did not affect $\mathrm{rPL}-\mathrm{II}$ secretion for 2-3 days of incubation. These results indicate that this in vitro culture system is suitable for elucidating the regulation of rPL-II secretion and that rat growth hormone and rat prolactin did not directly inhibit rPL-II secretion. They also suggest that insulin may play a role in regulating rPL-II secretion in vivo.
\end{abstract}

\section{Introduction}

The gestational profiles of rat placental lactogen II (rPL-II) are characterized by a sustained increase in maternal circulation during the last half of pregnancy (Robertson and Friesen, 1981; Kishi et al., 1991), a temporary increase in amniotic fluid at midpregnancy and low concentrations in fetal circulation at late pregnancy (Kishi et al., 1991). The secretion of rPL-II is considered to be controlled by factors from the pituitary (Daughaday et al., 1979; Robertson et al., 1984a), the ovary and the fetus (Robertson et al., 1984a, b; Tonkowicz and Voogt, 1984). Although the mechanisms by which these factors regulate rPL-II secretion still remain to be determined, in vivo experiments have shown that pituitary and ovarian factors inhibit, whereas fetal factors stimulate, rPL-II secretion (Robertson et al., 1984a, b; Tonkowicz and Voogt, 1984). The pituitary inhibitory

Received 31 December 1992. factors are postulated to be the substances that are secreted in the absence of direct hypothalamic control (Voogt et al., 1985). These pituitary factors have not yet been identified in rats, although mouse growth hormone has been determined to be a potent factor (Kishi et al., 1988). In addition to the abovementioned factors, in humans (h), growth factors including insulin, insulin-like growth factor I (IGF-I) and epidermal growth factor (EGF) stimulate hPL secretion and are involved in the differentiation of human trophoblast cells (Hochberg et al, 1983; Bhaumick et al., 1987; Maruo et al., 1987; Morrish et al., 1987). In contrast to such systemic factors, the rat placenta is a rich source of hypothalamic neuropeptides including growth hormone-releasing hormone (GHRH) (Baird et al., 1985; Meigan et al., 1988). It is speculated that rPL-II secretion may also be regulated by these local factors on the basis of the findings in humans (Khodr and Siler-Khodr, 1980; Shibasaki et al., 1982). However, no information is available as to whether placental peptides and growth factors are involved in controlling rPL-II secretion in rats. 
The present study was undertaken to develop a primary culture system using serum-free medium for rat placental trophoblast cells and to use it to examine whether these hormones are directly involved in controlling rPL-II secretion.

\section{Materials and Methods}

\section{Animals}

Mature virgin (8-week-old) Sprague-Dawley (Jcl:SD) rats were purchased from CLEA Japan Inc. (Ishibe, Shiga). The animals were maintained under controlled conditions of temperature $\left(23 \pm 1^{\circ} \mathrm{C}\right)$ and humidity on a $12 \mathrm{~h}$ light:12 $\mathrm{h}$ dark schedule and provided with laboratory chow and water ad libitum. Timing of pregnancies was determined by daily vaginal examination of each female housed with a male. The females with spermatozoa in the vaginal smear were considered pregnant and this day was designated day 0 of pregnancy.

\section{Hormones and reagents}

Rat placental lactogen-II (rPL-II) was purified and characterized in this laboratory (Kishi et al., 1992). Antibody to rPL-II was raised in rabbits and a homologous radioimmunoassay for rPL-II was developed in this laboratory (Kishi et al., 1992). Bovine insulin was purchased from Collaborative Research Inc. (Bedford, MA). Recombinant human IGF-I and IGF-II were from Bachem Inc. (Torrance, CA). Murine EGF was purchased from Gibco Laboratories (Grand Island, NY). Human GHRH, rat/ human corticotrophin-releasing hormone $(\mathrm{CRH})$ and LHRH were from Peptide Institute Inc. (Minoh, Osaka). Rat GH (NIADDK-Rat GH-B-8) and rat prolactin (NIADDK-Rat PRL-B-5) were a generous gift from NIADDK. Medium 199 with Hanks' salt, Waymouth's medium (10x), antibiotic-antimycotic, and fetal calf serum were purchased from Gibco Laboratories. Gentamicin reagent solution was from ICN Biomedical Inc. (Costa Mesa, CA). Medium SFM-101 was from Nissui Pharmaceutical Co. Ltd (Toshima-ku, Tokyo). Percoll and density marker beads were purchased from Pharmacia Fine Chemicals (Uppsala). Collagenase (type I), bovine pancreas deoxyribonuclease I (DNAase, type II), and calf thymus DNA were purchased from Sigma Chemical Co. (St Louis, MO).

\section{Dissection of the placenta and cell dissociation}

Pregnant rats were killed on day 13 . The uteri were quickly removed and placed into sterile dissociation medium (Medium

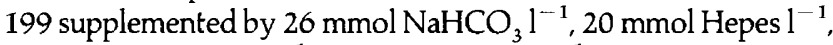
$50 \mu \mathrm{g}$ gentamicin $\mathrm{ml}^{-1}, 50 \mathrm{U}$ penicillin $\mathrm{ml}^{-1}$ and $50 \mu \mathrm{g}$ streptomycin $\mathrm{ml}^{-1}, \mathrm{pH}$ 7.4). The uterine wall was cut and individual conceptuses were removed without the decidual basalis under phase contrast microscopy (Nikon model SMZ, Nikon Optical Co., Tokyo). The decidua capsularis was then cut, and the fetus and the fetal membranes were removed. The basal zone and the labyrinth were collected in a conical polypropylene tube. The tissue was finely minced on a Teflon block with a singleedged razor blade. The minced tissue was transferred to a trypsinization flask, and dissociation medium containing $0.1 \%$ collagenase and $0.002 \%$ DNAase was added $\left(20 \mathrm{ml} \mathrm{g}^{-1}\right.$ tissue $)$.
The dissociation was carried out in a shaking water bath at $37^{\circ} \mathrm{C}$ for $60 \mathrm{~min}$ or more, and the progress of the dissociation was assessed under an inverted tissue microscope (Nikon model DIAPHOT-TMD, Nikon Optical Co.). The dissociated tissue was filtered through $150 \mu \mathrm{m}$ screen of Cellector (Bellco Glass, Inc., Vineland, NJ) to eliminate any undigested tissue pieces. The dissociated tissue was centrifuged at $170 \mathrm{~g}$ for $5 \mathrm{~min}$ to remove the medium containing collagenase and DNAase, and the pellet was resuspended in $2 \mathrm{ml}$ of dissociation medium with a Pasteur pipette. The resuspended cells were centrifuged at $700 \mathrm{~g}$ for $15 \mathrm{~min}$ through a $40 \%$ Percoll density gradient, which was prepared at $30000 \mathrm{~g}$ for $15 \mathrm{~min}$ just before use as described by Thordarson et al. (1987). After centrifugation, each fraction was collected with a Pasteur pipette according to the scale indicated on the surface of the outer conical tube (fractions $A-E)$, washed in dissociation medium to remove Percoll by centrifugation ( $170 \mathrm{~g}, 5 \mathrm{~min}$ ) and resuspended in $1 \mathrm{ml}$ of incubation medium. The number of cells was estimated using a haemocytometer by microscopy.

\section{Cell culture}

Cells from each fraction. The cells from each fraction were resuspended at concentrations of $0.5-1 \times 10^{6}$ cells $\mathrm{ml}^{-1}$ in medium SFM-101, which was supplemented by $26 \mathrm{mmol}$ $\mathrm{NaHCO}_{3} 1^{-1}, 20 \mathrm{mmol}$ Hepes $1^{-1}, 50 \mu \mathrm{g}$ gentamicin $\mathrm{ml}^{-1}$,

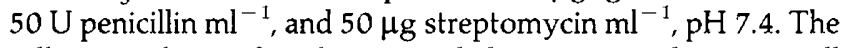
cells in a volume of $1 \mathrm{ml}$ were seeded in a $16-\mathrm{mm}$-diameter well coated with $1 \mathrm{ml}$ of collagen gel from rat tail in plastic multiwell plates (Cluster 24, Castar; Cambridge, MA), and incubated at $37^{\circ} \mathrm{C}$ under $95 \%$ air: $5 \% \mathrm{CO}_{2}$ for up to 7 days. The medium was changed every day and stored at $-20^{\circ} \mathrm{C}$ until assay. The cultured cells of three wells were harvested daily for DNA assay.

Effects of hormones on rPL-II secretion. The effects of insulin and other peptide hormones were examined using medium SFM-101, which contains $10 \mu \mathrm{g}$ bovine insulin $\mathrm{ml}^{-1}$, or the preparation without it (medium SFM-101 w/o). For the experiment with insulin addition, cells from fraction $B$ were used at the concentration of $5.5 \times 10^{5} \mathrm{cells} \mathrm{ml}^{-1}$. Bovine insulin was dissolved in $10 \mathrm{mmol} \mathrm{NaHCO}_{3} \mathrm{l}^{-1}, \mathrm{pH} 8.3$, and added to medium SFM-101 w/o in concentrations of 0.1, 1, 5, 10 and $20 \mu \mathrm{g} \mathrm{ml}^{-1}$. The cells in a volume of $1 \mathrm{ml}$ were seeded and incubated for 7 days as described above. For the experiment in which other peptide hormones were added, the cells from fractions $\mathrm{A}$ and $\mathrm{B}$ were pooled $\left(1.0 \times 10^{6} \mathrm{cells} \mathrm{ml}^{-1}\right.$ per well $)$ and preincubated for $24 \mathrm{~h}$ in the medium SFM-101. IGF-I, IGF-II, EGF, GHRH, CRH and LHRH were dissolved in medium SFM$101 \mathrm{w} / \mathrm{o}$ at the concentrations of $0.001-10$ or $0.1-10 \mu \mathrm{g} \mathrm{ml}^{-1}$. $\mathrm{rGH}$ and rat prolactin were dissolved in $10 \mathrm{mmol} \mathrm{NaHCO} \mathrm{l}^{-1}$, $\mathrm{pH} 8.3$, and added to medium SFM-101 w/o at concentrations of $0.1-10 \mu \mathrm{g} \mathrm{ml}^{-1}$. Controls were incubated in identical media without hormones. After preincubation, the cells were rinsed two to three times with medium SFM-101 w/o to remove cells not adhering to the collagen gel, and then incubated in media supplemented by either hormone with daily change of media for an additional 2 days as described above. The media were stored at $-20^{\circ} \mathrm{C}$ until assay for rPL-II. 


\section{Immunocytochemistry}

The cells from fraction $\mathrm{B}$ were placed in tissue culture chamber slides (Lab-Tek, Nunc, Inc., Naperville, IL) and incubated on medium SFM-101 for two days under the conditions described above. Cells were harvested on day 2 of incubation and rinsed with phosphate-buffered saline to remove excess media and fixed at room temperature overnight in a freshly prepared solution of $10 \mathrm{mmol}$ sodium metaperiodate $1^{-1}$, $75 \mathrm{mmol}$ lysine $\mathrm{I}^{-1}, 2 \%$ paraformaldehyde, and $37 \mathrm{mmol}$ sodium phosphate $\mathrm{l}^{-1}$, pH 7.4 (McLean and Nakane, 1974) containing $0.1 \%$ Tween 20 . The fixed cells were rinsed several times with phosphate-buffered saline and stained immunocytochemically using avidin-biotin immunoperoxidase kit for rabbit IgG (Vector Labs., Inc., Burlingame, CA). The immunostained cells were counterstained with haematoxylin. The chorioallantoic placentae on days 13 and 16 of pregnancy were fixed in buffered $10 \%$ formaldehyde solution and embedded in paraffin wax. The tissue preparation was used for immunocytochemical analysis as described above. Rabbit anti-rPL-II serum was used at a dilution of 1:500. The specificity of anti-rPL-II has been characterized (Kishi et al., 1992).

\section{DNA assay}

The DNA content of the cells in each well was determined by the method of Hinegardner (1971) using calf thymus DNA as a standard.

\section{Statistical analysis}

All the data from four or more groups for medium rPL-II concentrations were initially analysed for homogeneity of variance with Bartlett's test. Data meeting this criterion were analysed by one-way analysis of variance and subsequently by Scheffe's test. The data that showed heterogeneity of variance were analysed initially by the Kruskal-Wallis test and then by Scheffe's test. The data from two groups were initially analysed for homogeneity of variance with $F$-test. Data meeting this criterion were analysed by Student's unpaired $t$ test. The data that showed heterogeneity of variance were analysed by Aspin-Welch test. Differences with $P<0.05$ were considered significant.

\section{Results}

\section{Characteristics of the Percoll gradient-purified cells}

Placental cell suspensions obtained by enzymatic digestion were fractionated by Percoll gradient centrifugation (Fig. 1). Morphological observations of the cells collected from each fraction revealed that on day 0 of incubation cell debris and dead cells were at the top of the gradient. The following top two fractions (A, B) contained at least three types of cell: giant cells with a single nucleus or multinuclei, round cells and small round cells. The cells existed in clumps or as a single cell. The round cells predominated and no conspicuous distinction was observed in their cell population between fraction A and B
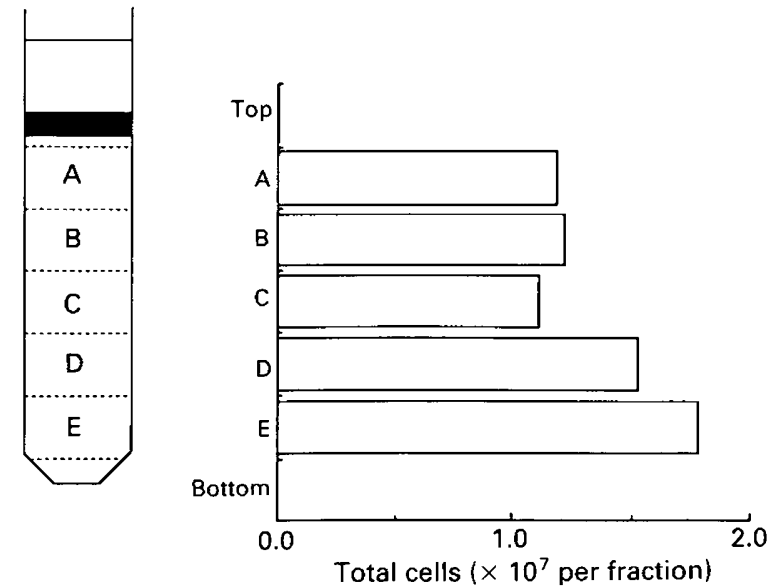

Fig. 1. Fractionation of placental cell suspension by the Percoll density gradient and the number of cells from each fraction. The cells were loaded at the top of the tube and, after centrifugation, the number of cells in each fraction was counted separately, and incubated in serum-free medium for 7 days.

except for the size of clumps. The clumps in fraction $\mathrm{A}$ were larger than those in fraction $B$. At fraction $C_{r}$ most cells existed as single cells. Although there were round cells, the population consisted predominantly of small round cells. Fractions D and E contained small round cells predominantly and a larger total number of cells than the other top three fractions.

Within $24 \mathrm{~h}$, at fractions A and B, giant cells and round cells adhered to the collagen bed. These cells growing in the centre of a confluent sheet were usually regular or polygonal (Fig. 2a, b), while the others growing at low cell density were more irregular, distended and became fibroblast-like in multipolar or bipolar shapes as incubation progressed. The rPL-IIproducing cells from fractions $\mathrm{A}$ and $\mathrm{B}$ were identified by immunocytochemical examination, resulting in approximately 59 and $69 \%$ of the cells being immunologically stained on day 2 of incubation, respectively. The immunostained cells consisted of giant cells and polygonal cells (Fig. 2a, b), and mononuclear cells predominated among them (approximately $88 \%$ in fraction B). The cells that were fibroblast-like in shape were also found by immunocytochemical determination to be producing rPL-II. In fraction $\mathrm{C}$, the round cells formed a few colonies of cells and distended, and became fibroblast-like in multipolar or bipolar shapes. Most of the cells were small round cells and were removed by rinsing because they did not adhere to the collagen bed. No adhesion of the cells to the collagen bed was observed in fractions $\mathrm{D}$ and $\mathrm{E}$ except for a small number of small round cells, and most of these were removed by rinsing. Immunocytochemical examination was therefore not made in fractions $C, D$ and $\mathrm{E}$.

The localization of rPL-II-producing cells in the chorioallantoic placenta is shown (Fig. 2c-f). Trophoblast giant cells located specifically at the interface between the decidua basalis and junctional zone were stained immunocytochemically on day 13 of pregnancy (Fig. 2c, d); corresponding to day 0 of incubation. Although the trophoblast giant cells associated with the decidua basalis remained rPL-II positive, rPL-II production was also observed in cells in the labyrinth zone by day 16 of pregnancy (Fig. 2e, f). Cells producing rPL-Il in the labyrinth zone were 

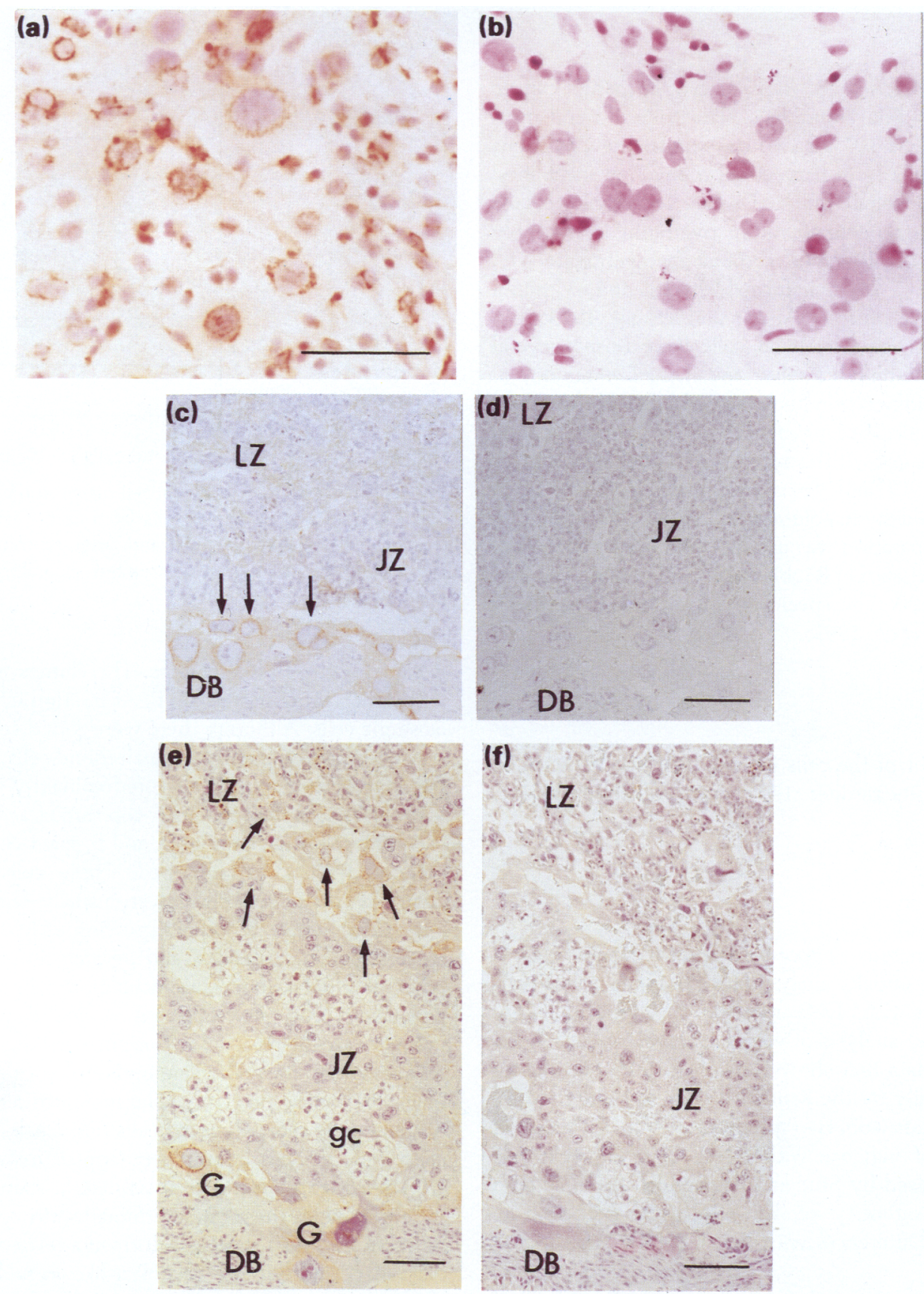

Fig. 2. Immunocytochemical staining of cultured trophoblast cells and the chorioallantoic placenta. Rat placental lactogen II (rPL-II) was detected with a rabbit antiserum to rPL-II ( $a, c$ and e), and controls were stained with preimmune rabbit serum $(b, d$ and $f)$. The cultured cells and placental tissue were also counterstained with haematoxylin. (a, b) Cultured cells on day 2 of incubation. Note the intense staining in both the giant cell and smaller cells. (c, d) Chorioallantoic placenta on day 13 of pregnancy (corresponding to day $\mathrm{O}$ of incubation). Note the intense staining in only giant cells associated with the decidua basalis (arrows). (e, f) Chorioallantoic placenta on day 16 of pregnancy. Note the intense staining in both the giant cells associated with the decidua basalis $(G)$ and the cells in the labyrinth zone (arrows). DB: decidua basalis; JZ: junctional zone; LZ: labyrinth zone; G: giant cell; gc: glycogen cell. The bar represents $0.1 \mathrm{~mm}$.

smaller than the giant cells associated with the decidua basalis and consisted of mono- or binuclear cells.

The overall pattern of medium rPL-II concentrations is characterized by a rapid increase in the first 2 days, high concentrations for the following $2-3$ days and a rapid decrease in the last 2 days (Fig. 3). Among the five fractions, rPL-II concentrations per well were usually highest in fraction $B$ (density, $1.05 \mathrm{~g} \mathrm{ml}^{-1}$ ) for days 2-7 (Fig. 3a). Concentrations of rPL-II per DNA did not change on days 2-5 of incubation and the DNA content of the cells from fraction $B$ decreased as incubation 

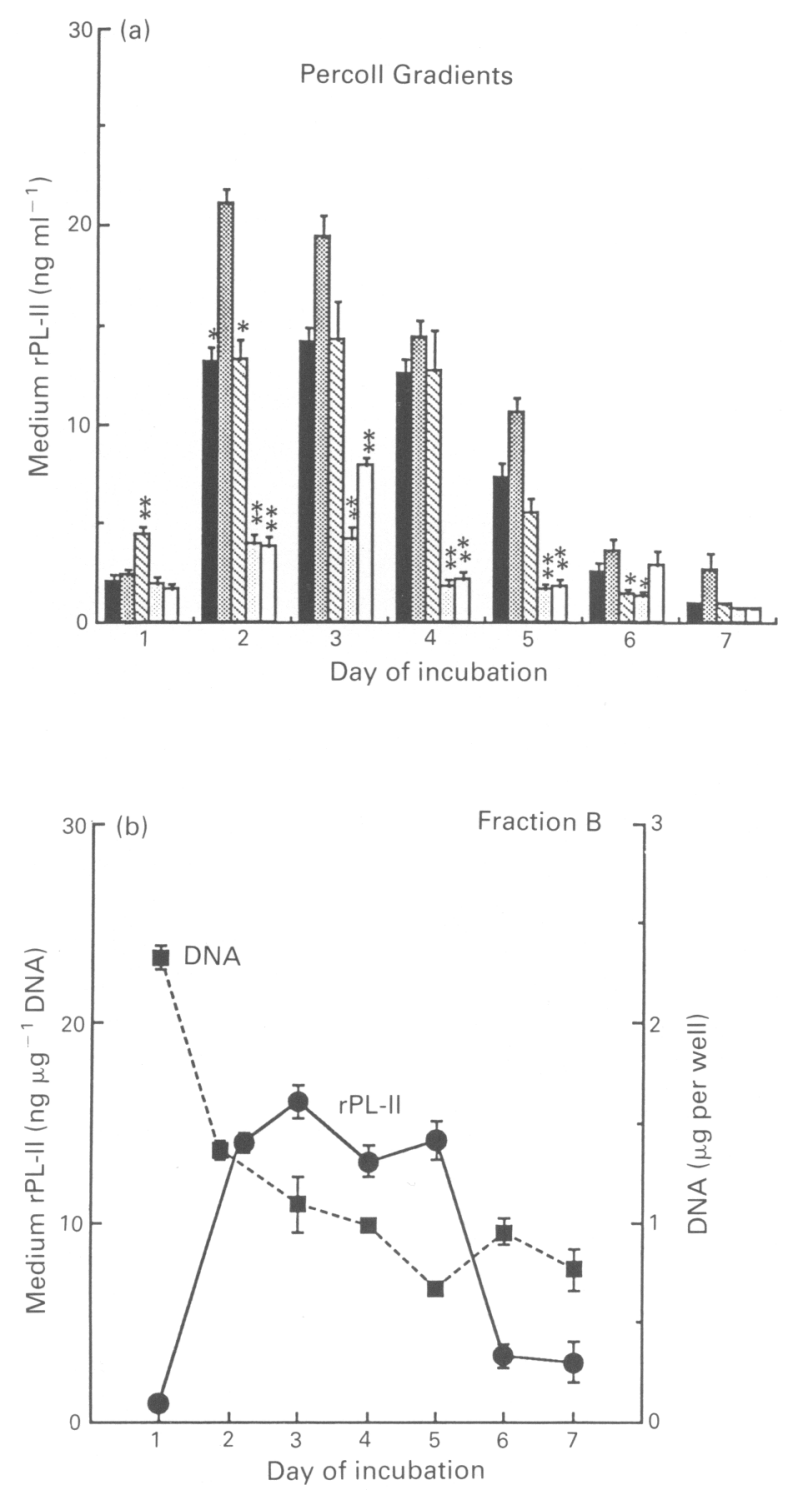

Fig. 3. (a, b) Time course of rat placental lactogen II (rPL-II) secretion and (b) total DNA content of fractionated trophoblast cells cultured on rat tail collagen bed for 7 days. Medium rPL-II concentrations expressed (a) per well and (b) per DNA, respectively. The cultured cells of three wells were harvested daily. Each point and bar represent mean \pm SEM of 3-21 samples. (a) ( $\square$ ) Fraction $A_{\text {; }}$ (图) Fraction $B$; (ब) Fraction C; (圈) Fraction D; ( $\square$ ) Fraction E. (b) () DNA; (O) rPL-II. ${ }^{*}{ }^{* *} P<0.05,0.01$ compared with fraction $\mathrm{B}$, respectively.

progressed (Fig. 3b). The incubation profile of DNA content of the cells from fraction $A$ was almost the same as those from fraction $B$ (data not shown).

Viability of seeded cells significantly deteriorated when they were incubated without a collagen bed, and no live cells were observed 1 or 2 days after incubation. Dissolution of the collagen bed also affected cell viability, and caused cell death within $24 \mathrm{~h}$. The effect of serum supplementation to culture medium on rPL-II secretion is shown (Table 1). rPL-II concentration in medium supplemented by fetal calf serum was approximately two to four times higher than those in serum-free medium. No differences in the DNA content of the cells cultured in medium with and without fetal calf serum was observed on the last day of incubation (day 6; Table 1).

\section{Effects of hormones on rPL-II secretion}

The cells from fractions A and B were pooled, and used for studies of effects of hormones, except insulin on rPL-II secretion, on the basis of the above-mentioned results. For example, no conspicuous differences in morphology of cultured cells were observed between fractions $A$ and $B$ during incubation. The number of rPL-II-producing cells accounted for approximately $59 \%$ of the total cultured cells of fraction $\mathrm{A}$. Concentrations of rPL-II in fraction A remained high during incubation, although those in fraction $\mathrm{A}$ were lower than those in fraction B. Furthermore, pooling prevents waste of dissociated cells.

Insulin stimulated rPL-II secretion in a dose-dependent manner by day 6 of incubation (Fig. 4). At doses of 10 and $20 \mu \mathrm{g} \mathrm{ml}^{-1}$, significant increases in rPL-II secretion were observed throughout the experiment, except for the last day of incubation. The effective dose of insulin was found to be $0.1 \mu \mathrm{g} \mathrm{ml}^{-1}$.

Growth factors, IGF-I, IGF-II, $\left(0.1-1 \mu \mathrm{g} \mathrm{ml}^{-1}\right)$ and EGF $\left(0.001-10 \mu \mathrm{g} \mathrm{ml}^{-1}\right)$, did not produce any changes of medium rPL-II concentrations throughout the experiments (Fig. 5). In addition, no changes were caused by pituitary hormones $\mathrm{rGH}$ and rat prolactin at doses of $0.1-10 \mu \mathrm{g} \mathrm{ml}^{-1}$ (Fig. 6). Concentrations of rPL-II did not change by addition of $\mathrm{CRH}$ and LHRH at doses of $0.1-10 \mu \mathrm{g} \mathrm{ml}^{-1}$. GHRH stimulated rPL-II secretion at doses of $1-10 \mu \mathrm{g} \mathrm{ml}^{-1}$ in a dose-dependent manner only during the first $24 \mathrm{~h}$ of exposure to the hormone (day 2), and on the following day no change of the medium rPL-II concentration was observed (Fig. 7).

\section{Discussion}

Percoll gradient centrifugation yielded efficient separation of rPL-II-producing cells from digested tissue from labyrinth and junctional zones of the chorioallantoic placenta. Fraction $B$ was found to be enriched with rPL-II-producing cells. These cells adhered to the collagen bed as a monolayer and consisted of mononuclear or binuclear giant cells and polygonal cells. The morphology of adhered cells depended upon cell density; cells growing at high cell density were epithelial-like and those at low cell density fibroblast-like. The population of cultured cells consisted of a few trophoblast giant cells and polygonal cells. The rPL-II-producing cells from fraction $B$, which were identified by immunocytochemistry using anti-rPL-II serum, accounted for approximately $69 \%$ of total cultured cells on day 2 of incubation. Although all the giant cells were found to be producing rPL-II, most of the rPL-II-positive cells were polygonal cells, which were smaller than the giant cells. These results are in agreement with the results obtained in vivo; which showed that trophoblast giant cells associated with the decidua basalis remained rPL-II positive on day 16 of pregnancy. Furthermore, the localization of rPL-II-producing cells in vivo in the chorioallantoic placenta varied as pregnancy progressed, and rPL-II-producing cells were also found in the 
Table 1. Effect of fetal calf serum on rat placental lactogen II (rPL-II) secretion by cultured trophoblasts

\begin{tabular}{|c|c|c|c|c|c|c|c|c|}
\hline \multirow[b]{2}{*}{ Media } & \multirow{2}{*}{$\begin{array}{l}\text { Number } \\
\text { of wells }\end{array}$} & \multicolumn{6}{|c|}{ Medium rPL-II concentrations (ng $\mathrm{ml}^{-1}$ ) } & \multirow{2}{*}{$\begin{array}{c}\text { DNA content } \\
(\mu \mathrm{g} \text { per well; day } 6)\end{array}$} \\
\hline & & Day 1 & Day 2 & Day 3 & Day 4 & Day 5 & Day 6 & \\
\hline Serum-free & 4 & $86 \pm 10$ & $268 \pm 17$ & $305 \pm 20$ & $24.3 \pm 4$ & $163 \pm 11$ & $101 \pm 10$ & $1.68 \pm 0.038$ \\
\hline $\begin{array}{l}\text { Fetal calf serum } \\
\quad(10 \%)\end{array}$ & 4 & $121 \pm 15$ & $477 \pm 27^{* *}$ & $721 \pm 59^{* *}$ & $756 \pm 102^{*}$ & $686 \pm 146^{*}$ & $471 \pm 31^{* *}$ & $1.58 \pm 0.065$ \\
\hline
\end{tabular}

Media were changed daily. Values given are means \pm SEM. ${ }^{*} P<0.05,{ }^{* *} P<0.01$.

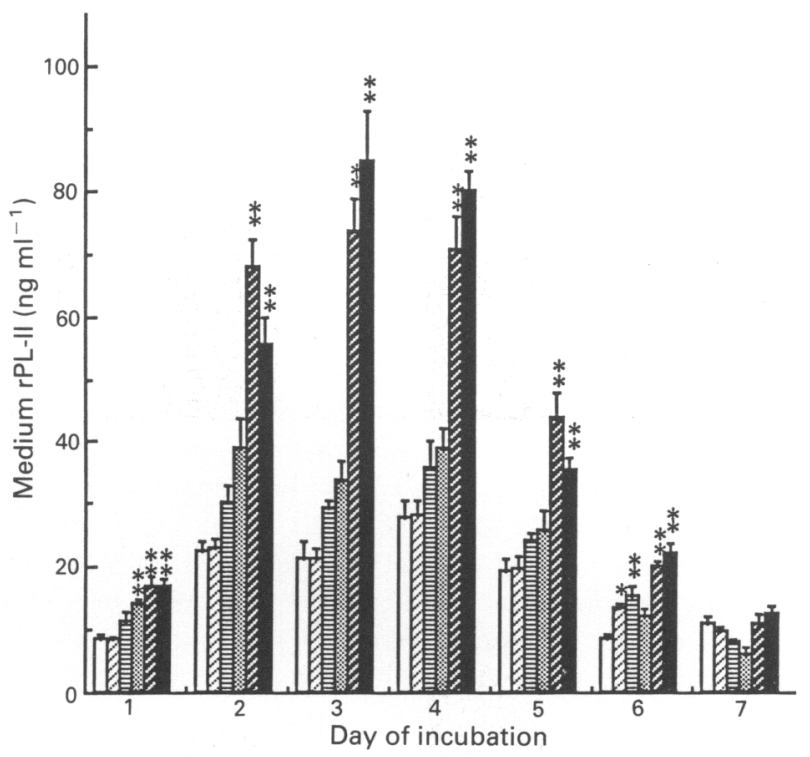

Fig. 4. Effect of insulin on rat placental lactogen II (rPL-II) secretion by cultured trophoblast cells for 7 days of incubation. Each bar represents mean $\pm \mathrm{SEM}$ of eight samples. ( $\square$ ) control; () $0.1 \mu \mathrm{g} \mathrm{m}^{-1}$; (目) $1.0 \mu \mathrm{g} \mathrm{ml}^{-1}$; (圆) $5.0 \mu \mathrm{g} \mathrm{ml}^{-1}$; (四) $10 \mu \mathrm{g} \mathrm{ml}^{-1}$; (口) $20 \mu \mathrm{g} \mathrm{ml}^{-1}$. ${ }^{*},{ }^{* *} P<0.05,0.01$ compared with control, respectively.

labyrinth zone. The rPL-II-producing cells in the labyrinth zone were smaller than the giant cells associated with the decidua basalis. This profile of functional differentiation of trophoblast cells in producing rPL-II in vivo is similar to the reports of Campbell et al. (1989) and Duckworth et al. (1990). The incubation profiles of the number of rPL-II-producing cells were not examined in this experiment. The population of rPL-IIproducing cells in vitro may vary as trophoblast cells from the labyrinth zone will differentiate to produce rPL-Il as incubation is prolonged. It is interesting that $\mathrm{rPL}-\mathrm{Il}$ is also produced in cells in the labyrinth zone where rPL-II could have access to the fetal blood supply. However, it still remains unclear whether rPL-II also has a function in the fetus. Because our previous work has shown that rPL-II is present in very small amounts in fetal serum only on days 17 and 18 , and is less than $1 \%$ of the maternal circulation during late pregnancy (Kishi et al., 1991).

Concentrations of rPL-II per DNA were not changed on days 2-5 of incubation, although the DNA content of the cells from fraction $B$ decreased as incubation was prolonged. The collagen bed is necessary for the viability and growth of the cultured

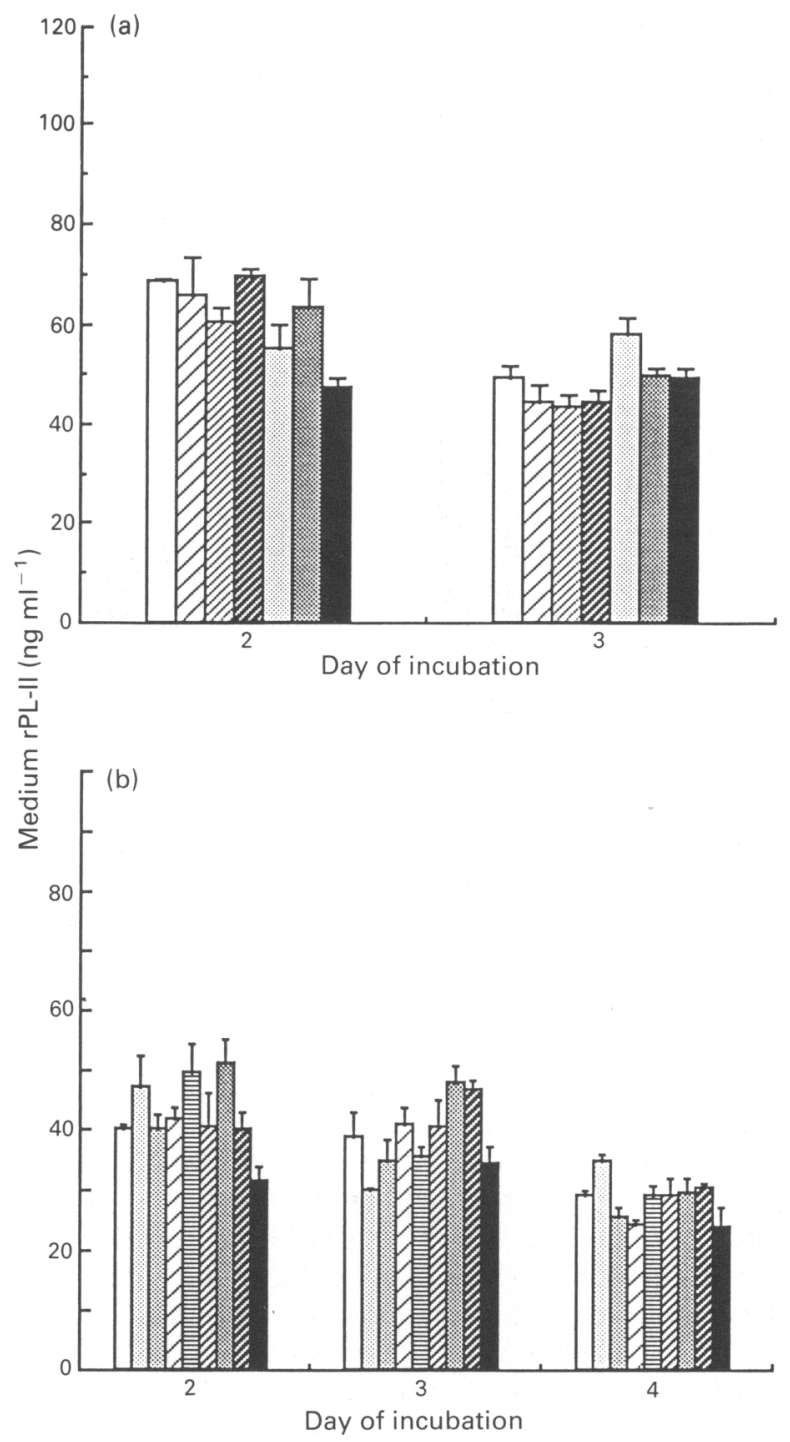

Fig. 5. Effect of (a) IGF-I, IGF-II and (b) EGF on rat placental lactogen II (rPL-II) secretion by cultured trophoblast cells for (a) 2-3 days, and (b) 2-4 days, of incubation. Each bar represents mean \pm SEM of four samples. IGF-I: ( $\square$ ) control; (田) $0.1 \mu \mathrm{g} \mathrm{ml}^{-1}$; (囚) $0.5 \mu \mathrm{g} \mathrm{ml}^{-1}$; (因) $1.0 \mu \mathrm{g} \mathrm{ml}^{-1}$. IGF-II: ( $\square$ ) control; (圈) $0.1 \mu \mathrm{g} \mathrm{ml}^{-1}$; (㬝) $0.5 \mu \mathrm{g} \mathrm{ml}^{-1}$; (口) $1.0 \mu \mathrm{g} \mathrm{m}^{-1}$. EGF:( $\square$ ) control; (图) $0.001 \mu \mathrm{g} \mathrm{ml}^{-1}$; (图) $0.01 \mu \mathrm{g} \mathrm{ml}^{-1}$; (可 $0.05 \mu \mathrm{g} \mathrm{ml}^{-1}$; (目) $0.1 \mu \mathrm{g} \mathrm{ml}^{-1}$; (四) $0.5 \mu \mathrm{g} \mathrm{ml}^{-1}$; (㼩) $1 \mu \mathrm{g} \mathrm{m}^{-1}$, (圈) $5 \mu \mathrm{g} \mathrm{ml}^{-1}$; ( $) 10 \mu \mathrm{g} \mathrm{ml}^{-1}$. 


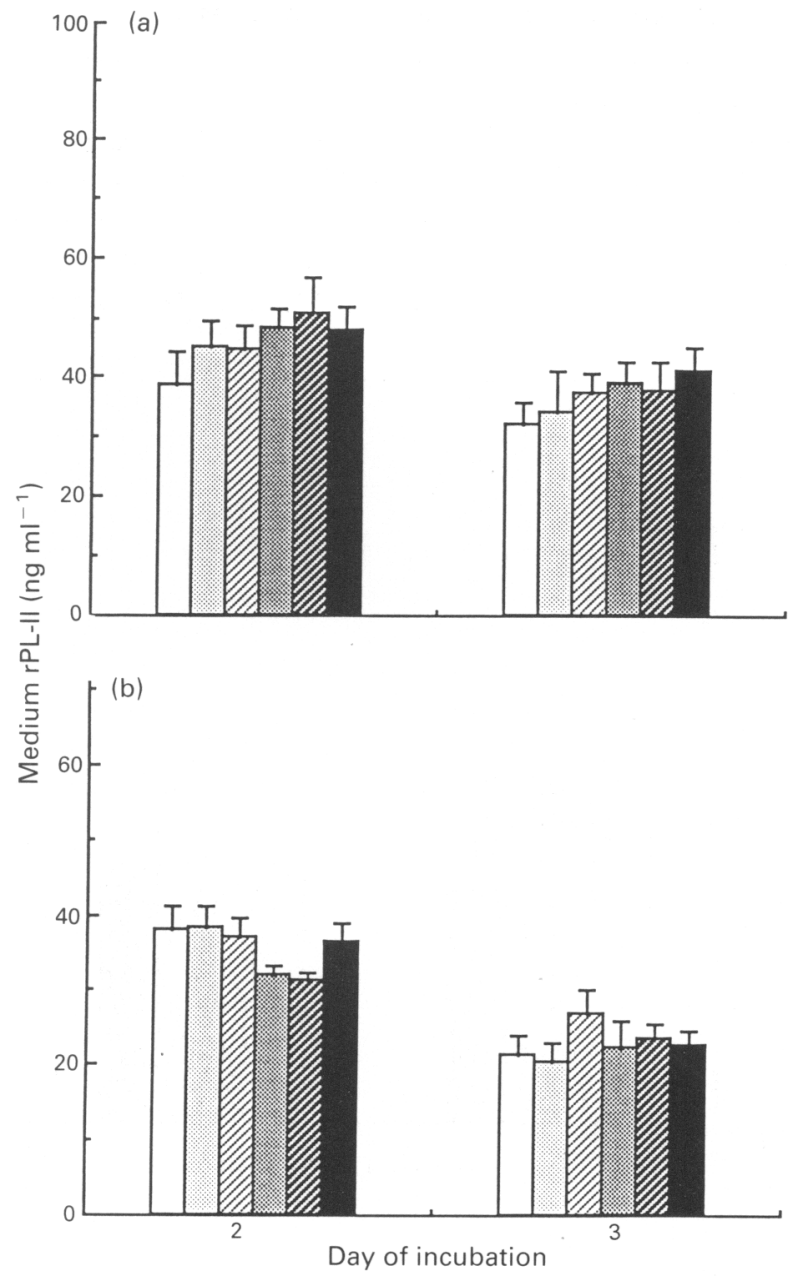

Fig. 6. Effect of (a) rat growth hormone and (b) rat prolactin on rat placental lactogen II (rPL-II) secretion by cultured trophoblast cells for 2-3 days of incubation. Each bar represents mean \pm SEM of four samples. Rat growth hormone and rat prolactin ( $\square$ ) control;

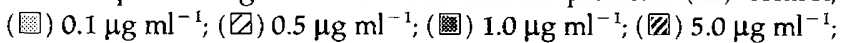
() $10 \mu \mathrm{g} \mathrm{ml}^{-1}$.

cells, as the viability decreased significantly when the collagen bed was dissolved and no cell growth was observed without it. The rat placental cell culture systems described by Ferguson and Palm, (1976) and Soares and Glasser (1987) used fetal calf serum, the addition of which allowed longer periods of incubation. In a preliminary experiment of this study, we confirmed that rat trophoblast cells expressed secretory function better when cultured in medium with fetal calf serum than when cultured without it. In addition supplementation of fetal calf serum did not affect DNA content of cultured cells, suggesting that fetal calf serum does not affect viability of cultured cells. In this experiment, however, we did not add sera to the incubation medium. The cultured cells without serum could secrete rPL-II, characterized by a rapid increase in the first 2 days and a decrease thereafter, for at least 7 days and responding to insulin for 6 days. Furthermore, it has been widely reported that serum supplementation in culture medium has a number of serious disadvantages for cell growth, differentiation or function in animal cell culture (Barnes, 1987; Freshney, 1987). The present system
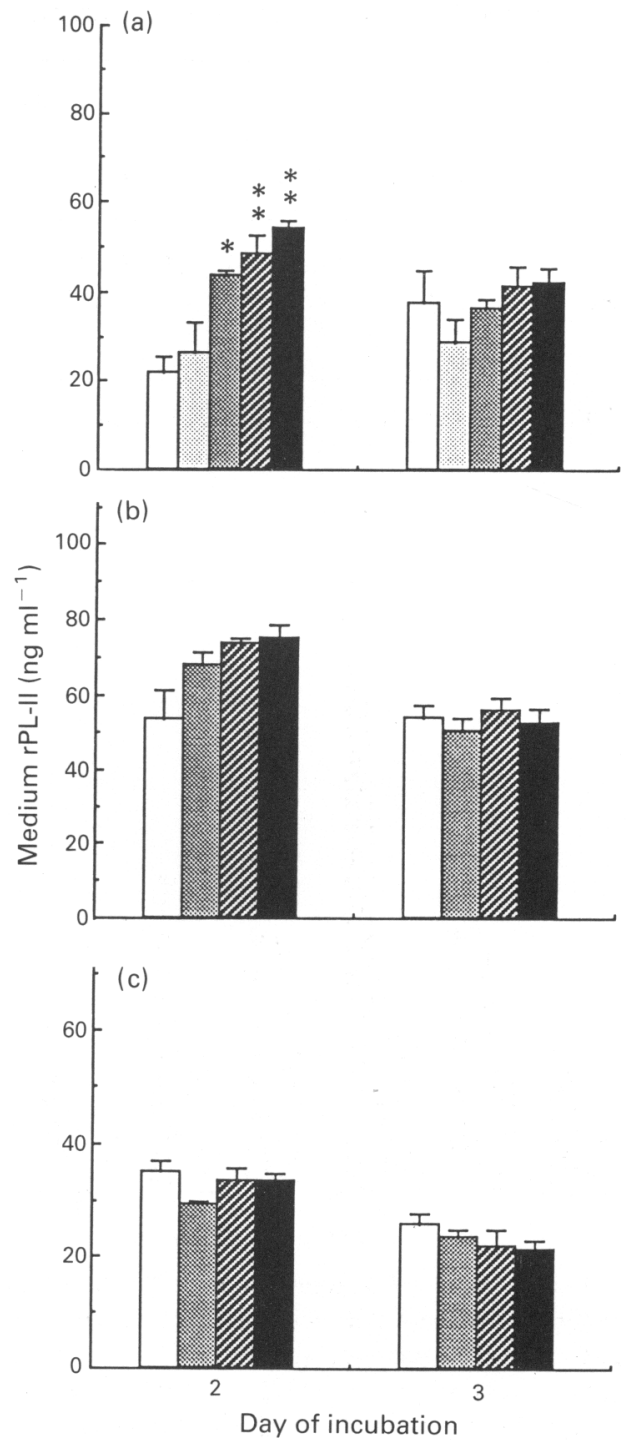

Fig. 7. Effect of (a) growth hormone-releasing hormone (GHRH), (b) corticotrophin releasing hormone $(\mathrm{CRH})$ and (c) LHRH on rat placental lactogen II (rPL-II) secretion by cultured trophoblast cells for 3 days of incubation. Each bar represents mean \pm SEM of four samples. GHRH: ( $\square$ ) control; (图) $0.1 \mu \mathrm{g} \mathrm{ml}^{-1}$; (圈) $1 \mu \mathrm{g} \mathrm{ml}^{-1}$; (囚) $5 \mu \mathrm{g} \mathrm{ml}^{-1}$; (口) $10 \mu \mathrm{g} \mathrm{ml}^{-1}$. CRH and LHRH: ( $\square$ ) control; (圆) $0.1 \mu \mathrm{g} \mathrm{ml}^{-1}$; (囚) $1.0 \mu \mathrm{g} \mathrm{ml}^{-1}$; (口) $10 \mu \mathrm{g} \mathrm{ml}^{-1} .{ }^{*},{ }^{*} P<0.05,0.01$ compared with control, respectively.

on a monolayer using serum-free medium permits study of the regulation of rPL-II secretion, without the effects of serum components such as binding proteins, extracellular enzymes and inhibitors.

Insulin stimulated rPL-II secretion in vitro in a dose-dependent manner throughout the experiment, suggesting that insulin has a physiological significance as a stimulating factor in regulating rPL-II secretion during the last half of pregnancy. The presence of abundant insulin receptors in the rat placenta (Posner, 1974) and the rise of immunoreactive insulin in maternal circulation, particularly during the last half of pregnancy (Knopp et al., 1973), support the involvement of insulin in controlling rPL-II secretion. A supraphysiological concentration of insulin Downloaded from Bioscientifica.com at 04/26/2023 10:46:32AM 
$\left(10 \mu \mathrm{g} \mathrm{ml}^{-1}\right)$, however, was required for optimal secretion of rPL-II, with an appreciable stimulation of rPL-II secretion at $0.1 \mu \mathrm{g} \mathrm{ml}^{-1}$. Although it is not clear why rPL-Il producing cells seem to require a high concentration of insulin in vitro, this does not rule out the possibility that insulin may be involved in regulating rPL-II secretion in rats. Insulin is known to accumulate in the rat placenta (Goodner and Freinkel, 1961), suggesting difficulty in appropriately evaluating the 'physiological' concentration of insulin in vitro. Furthermore, although rPL-II secretion is known to be inhibited by the pituitary (Daughaday et al., 1979; Voogt et al., 1985) and ovaries (Robertson et al., 1984a, b) in vivo a greater amount of insulin may be required to allow further secretion in addition to secretion in the absence of inhibitory factors. The day of pregnancy on which the dissection was done may correlate with the sensitivity to insulin, as the cytotrophoblast cells in the placenta differentiate rapidly particularly during the last half of pregnancy (Campbell et al., 1989). It remains to be determined whether there is a difference in sensitivity to insulin of the cells isolated between mid- and late pregnancy.

Insulin is also known to stimulate human placental lactogen secretion by cultured human trophoblast cells at doses in the physiological range (Hochberg et al., 1983). However, insulin inhibits mPL-II secretion by cultured mouse trophoblast cells (Thordarson et al., 1987). The differences in the action of insulin between rats and mice are not clear.

In contrast to the stimulatory effect of insulin on rPL-II secretion, lactogenic hormones, together with other gestational hormones, enhance insulin secretion induced by glucose stimulation and are associated with insulin resistance during late pregnancy (Martin and Friesen, 1969; Green and Taylor, 1972; Nielsen, 1982; Leturque et al., 1984; Ryan and Enns, 1988; Parsons et al., 1992). The metabolic changes induced by placental lactogens during pregnancy are considered to be required so that glucose is available for the growing fetuses. The stimulatory effect of insulin on rPL-II secretion observed in the experiment reported here may bring about further enhancement of rPL-II action as a gestational hormone in the mechanisms by which the maternal compartment responds to increased demand for glucose by the fetal compartment.

In the study reported here, the presence of IGF-I and IGF-II did not affect rPL-II secretion in vitro. Gestational profiles of IGF-I and IGF-II in maternal circulation of rats are characterized by the highest concentrations in early to mid-pregnancy and the lowest ones in late pregnancy, and detectable concentrations during pregnancy, respectively (Moses et al., 1980; Gargosky et al., 1990). The mean concentrations of immunoreactive IGF-I in maternal circulation are reported not to exceed $1000 \mathrm{ng} \mathrm{ml}^{-1}$. The doses of IGF-I and IGF-II used in this experiment covered a wide range of concentrations from physiological values to those exceeding them with respect to the circulating concentrations of IGFs. We therefore concluded that IGF-I and IGF-II are not involved in direct control of rPL-II secretion in rats. However, IGF-I has been found to be ten times more potent than is insulin in stimulating hPL secretion by human term placental explants (Bhaumick et al., 1987). During the last half of pregnancy, rat placental expression of IGF-II mRNA is similar to that of rPL-II mRNA (Duckworth et al, 1986; Pescovitz et al., 1991). Further studies are needed on the relationship between IGFs and PL-II, in addition to studies to explain the species differences in the effects of IGFs on PL secretion between rats and humans.

Epidermal growth factor has been found to induce large sustained increases in hPL secretion by cultured human trophoblast cells in a dose-dependent manner (Maruo et al., 1987; Morrish et al., 1987), and it has been suggested that EGF plays a significant role in the morphological differentiation and function of trophoblast cells in humans. In the present study, no effect of EGF on rPL-II secretion was found during incubation for 2 days. Further studies should be carried out to determine whether a long period of EGF exposure is necessary for stimulation of rPL-II secretion by rat trophoblast cells, as human trophoblast cells require at least 2-4 days for significant enhancement of hPL secretion in vitro (Maruo et al., 1987; Morrish et al., 1987).

Secretion of rPL-II is considered to be under the control of the pituitary gland on the basis of the findings that hypophysectomy resulted in a rise in serum rPL-II in rats (Daughaday et al., 1979; Robertson et al., 1984b). The rise in rPL-II after hypophysectomy during the last third of pregnancy is reported to be suppressed by pituitary implant under the kidney capsule (Voogt et al., 1985). These findings suggest that the pituitary can secrete inhibitory substances in the absence of hypothalamic control. The putative inhibitory factors of the pituitary are considered to be rat prolactin or rat growth hormone, since the ectopic pituitary can secrete at least two hormones, rat prolactin and rat growth hormone, autonomously in rats (Panerai et al., 1977) and the rise in mPL-II after hypophysectomy can be suppressed by administration of mouse growth hormone but not mouse prolactin in mice (Kishi et al., 1988). In our experiments, individual addition of rat prolactin and rat growth hormone at concentrations covering physiological concentrations observed during pregnancy did not affect rPL-II secretion by cultured trophoblast cells. These results exclude the possibility of direct control of rPL-II secretion by rat growth hormone and rat prolactin. However, they do not rule out the possibility that these pituitary hormones are involved in indirect control of rPL-II secretion, because in mice, mouse growth hormone does not inhibit the rise in serum mPL-II after hypophysectomy in the absence of the ovaries and adrenals (Kishi, K., Ogren, L. and Talamantes, F., unpublished observations). Whether rGH or $\mathrm{rPRL}$ can suppress the rise in $\mathrm{rPL}-\mathrm{II}$ after hypophysectomy and how the adrenals and ovaries mediate the pituitary effects on rPL-II secretion remain to be determined.

Hypothalamic neuropeptides, including GHRH, CRH and LHRH, have been found in the rat and human placenta (Khodr and Siler-Khodr, 1980; Shibasaki et al., 1982; Baird et al., 1985; Meigan et al., 1988; Pescovitz et al., 1991). Of these peptides, GHRH in rat placenta has also been found to be immunoreactive and biologically active (Duckworth et al., 1986; Pescovitz et al., 1991). Placental expression of GHRH mRNA has been documented to be concurrent with maximal expression of placenta IGF-II as well as rPL-II mRNA (Meigan et al., 1988; Pescovitz et al., 1991). These findings suggest that hypothalamic peptides in the placenta have a role in regulating rPL-II secretion in rats. In this study, addition of GHRH to rat placental culture media caused stimulation of rPL-II secretion in a dose-dependent manner only during the first $24 \mathrm{~h}$ of exposure. However, it is not clear whether GHRH has physiological significance because no consistent effect was observed on rPL-II secretion in this study. CRH and LHRH did not affect rPL-II 
secretion in this experiment. These two peptide hormones are therefore not likely to play a role in directly regulating rPL-II secretion in rats.

The authors thank F. Talamantes and G. Thordarson of the University of California, Santa Cruz, and Y. Hasegawa and T. Kitamura of Shionogi Research Laboratories for their helpful advice, and NIADDK for providing the pituitary hormones.

\section{References}

Baird A, Wehrenberg WB, Böhlen P and Ling N (1985) Immunoreactive and biologically active growth hormone-releasing factor in the rat placenta Endocrinology 117 1598-1601

Barnes D (1987) Serum-free animal cell culture BioTechniques 5 534-542

Bhaumick B, Dawson EP and Bala RM (1987) The effects of insulin-like growth factor-I and insulin on placental lactogen production by human term placental explants Biochemical and Biophysical Research Communications 144 $674-682$

Campbell EJ, Deb S, Kwok SC, Joslin JA and Soares M) (1989) Differential expression of placental lactogen-II and prolactin-like protein- $A$ in the rat chorioallantoic placenta Endocrinology 125 1565-1574

Daughaday WH, Trivedi B and Kapadia M (1979) The effect of hypophysectomy on rat chorionic somatomammotropin as measured by prolactin and growth hormone radioreceptor assays: possible significance in maintenance of somatomedin generation Endocrinology 105 210-214

Duckworth ML, Kirk KL and Friesen HG (1986) Isolation and identification of a cDNA clone of rat placental lactogen II Joumal of Biological Chemistry 261 10871-10878

Duckworth ML, Schroedter IC and Friesen HG (1990) Cellular localization of rat placental lactogen II and rat prolactin-like protein A and B by in situ hybridization Placenta 11 143-155

Ferguson FG and Palm J (1976) Histologic characteristics of cells cultured from rat placental tissue American Joumal of Obstetrics and Gynecology 124 415-420

Freshney RI (1987) The culture environment: substrate, gas phase, medium, and temperature Culture of Animal Cells, pp 57-84 Ed. RI Freshney. Alan R Liss, New York

Gargosky SE, Walton PE, Owens PC, Wallace JC and Ballard FJ (1990) Insulinlike growth factor-I (IGF-I) and IGF-binding proteins both decline in the rat during late pregnancy Joumal of Endocrinology 127 383-390

Goodner CJ and Freinkel N (1961) Carbohydrate metabolism in pregnancy IV. Studies on the permeability of the rat placenta to ${ }^{13}$ I insulin Diabetes 10 383-392

Green IC and Taylor KW (1972) Effects of pregnancy in the rat on the size and insulin secretory response of the islets of Langerhans Joumal of Endocrinology $54317-325$

Hinegardner RT (1971) An improved fluorometric assay for DNA Analytical Biochemistry 39 197-201

Hochberg Z, Perlman R, Brandes JM and Benderli A (1983) Insulin regulates placental lactogen and estradiol secretion by cultured human term trophoblast journal of Clinical Endocrinology and Metabolism 57 1311-1313

Khodr GS and Siler-Khodr TM (1980) Placental luteinizing hormone-releasing factor and its synthesis Science 207 315-317

Kishi K, Ogren L, Southard JN and Talamantes F (1988) Pituitary factors regulating mouse placental lactogen-II secretion during the last half of pregnancy in mice Endocrinology 122 2309-2317

Kishi K, Hirashiba M and Hasegawa Y (1991) Gestational profiles of rat placental lactogen-II (rPL-II) and growth hormone (GH) in maternal and fetal serum, amniotic fluid, and placental tissue Endocrinologia Japonica 38 589-595

Kishi K, Hirashiba M and Hasegawa Y (1992) Multiple forms of rat placental lactogen-II (rPL-II): purification and partial characterization of rPL-II Placenta $1363-79$
Knopp RH, Saudek CD, Arky RA and O'Sullivan JB (1973) Two phases of adipose tissue metabolism in pregnancy: maternal adaptations for fetal growth Endocrinology 92 984-988

Leturque A, Burnol AF, Ferrë P and Girard J (1984) Pregnancy-induced insulin resistance in the rat: assessment by glucose clamp technique American journal of Physiology 246 E25-E31

McLean IW and Nakane PK (1974) Periodate-lysine-paraformaldehyde fixative a new fixative for immunoelectron microscopy Joumal of Histochemistry and Cytochemistry 22 1077-1083

Martin JM and Friesen $\mathbf{H}$ (1969) Effect of human placental lactogen on the isolated islets of Langerhans in vitro Endocrinology 84 619-621

Maruo T, Matsuo H, Oishi T, Hayashi M, Nishino R and Mochizuki M (1987) Induction of differentiated trophoblast function by epidermal growth factor: relation of immunohistochemically detected cellular epidermal growth factor receptor levels Journal of Clinical Endocrinology and Metabolism 64 744-750

Meigan G, Sasaki A and Yoshinaga K (1988) Immunoreactive growth hormonereleasing hormone in rat placenta Endocrinology 123 1098-1102

Morrish DW, Bhardwaj D, Dabbagh LK, Marusyk H and Siy O (1987) Epidermal growth factor induces differentiation and secretion of human chorionic gonadotropin and placental lactogen in normal human placenta Journal of Clinical Endocrinology and Metabolism 65 1282-1290

Moses AC, Nissley SP, Short PA, Rechler MM, White RM, Knight AB and Higa OZ (1980) Increased levels of multiplication-stimulating activity, an insulinlike growth factor, in fetal rat serum Proceedings of National Academy of Sciences USA 77 3649-3653

Nielsen JH (1982) Effects of growth hormone, prolactin, and placental lactogen on insulin content and release, and deoxyribonucleic acid synthesis in cultured pancreatic islets Endocrinology $110600-606$

Panerai AE, Gil-ad I, Cocchi D, Locatelli V, Rossi GL and Müller EE (1977) Thyrotrophin releasing hormone-induced growth hormone and prolactin release: physiological studies in intact rats and in hypophysectomized rats bearing an ectopic pituitary gland Journal of Endocrinology 72 301-311

Parsons JA, Brelje TC and Sorenson RL (1992) Adaptation of islets of Langerhans to pregnancy: increased islet cell proliferation and insulin secretion correlates with the onset of placental lactogen secretion Endocrinology 130 1459-1466

Pescovitz OH, Johnson NB and Berry SA (1991) Ontogeny of growth hormone releasing hormone and insulin-like growth factors-I and -II messenger RNA in rat placenta Pediatric Research 29 510-516

Posner BI (1974) Insulin receptors in human and animal placental tissue Diabetes 23 209-217

Robertson MC and Friesen HG (1981) Two forms of rat placental lactogen revealed by radioimmunoassay Endocrinology 108 2388-2390

Robertson MC, Owens RE, Klindt J and Friesen HG (1984a) Ovariectomy leads to a rapid increase in rat placental lactogen secretion Endocrinology 114 1805-1811

Robertson MC, Owens RE, Mccoshen JA and Friesen HG (1984b) Ovarian factors inhibit and fetal factors stimulate the secretion of rat placental lactogen Endocrinology $11422-30$

Ryan EA and Enns L (1988) Role of gestational hormones in the induction of insulin resistance Journal of Clinical Endocrinology and Metabolism 67 341-347

Shibasaki T, Odagiri E, Shizume K and Ling N (1982) Corticotropin-releasing factor-like activity in human placental extracts journal of Clinical Endocrinology and Metabolism 55 384-386

Soares MJ and Glasser SR (1987) Placental lactogen production and functional differentiation of rat trophoblast cells in vitro Joumal of Reproduction and Fertility 79 335-341

Thordarson G, Folger P and Talamantes F (1987) Development of a placental cell culture system for studying the control of mouse placental lactogen II secretion Placenta 8 573-585

Tonkowicz PA and Voogt JL (1984) Ovarian and fetal control of rat placental lactogen and prolactin secretion at midpregnancy Endocrinology 114 254-259

Voogt JL, Pakrasi PL, Johnson DC and Dey SK (1985) Evidence for pituitary regulation of placental lactogen in the rat Joumal of Endocrinology 107 121-126 